\title{
Pengaruh Pengawasan Keuangan, Penerapan Standar Akuntansi Pemerintah Berbasis Akrual, dan Kualitas Pelatihan Terhadap Keterandalan Pelaporan Keuangan
}

\author{
Ni Putu Noviyantini*, Sunitha Devi \\ Universitas Pendidikan Ganesha, Singaraja, Bali, Indonesia \\ *noviyantiniputu26@gmail.com
}

\author{
Riwayat Artikel: \\ Tanggal diajukan: \\ 19 Juni 2020 \\ Tanggal diterima: \\ 29 Agustus 2020 \\ Tanggal dipublikasi: \\ 31 Agustus 2020
}

Kata kunci: pengawasan keuangan, penerapan SAP berbasis akrual, kualitas pelatihan, keterandalan pelaporan keuangan

\begin{abstract}
Abstrak
Riset ini bertujuan untuk memahami pengaruh pengawasan keuangan, penerapan standar akuntansi pemerintah berbasis akrual, dan kualitas pelatihan terhadap keterandalan pelaporan keuangan. Jenis penelitian yang dipergunakan adalah penelitian kuantitatif. Adapun Populasi pada riset ini yakni semua pegawai sub bagian keuangan pada 27 SKPD di Kabupaten Badung. Metode penentuan sampel yang dipergunakan adalah purposive sampling. Jumlah sampel pada riset ini yakni sebanyak 108 responden. Riset ini mempergunakan data primer yang didapatkan dari pendistribusian kuesioner secara langsung kepada responden. Teknik analisis data yang dipergunakan meliputi uji statistik deskriptif, uji kualitas data, uji asumsi klasik, serta pengujian hipotesis menggunakan analisis regresi linear berganda dengan mempergunakan software IBM SPSS Statistics 23. Hasil riset membuktikan bahwa: (1) pengawasan keuangan berpengaruh positif dan signifikan terhadap keterandalan pelaporan keuangan; (2) penerapan standar akuntansi pemerintah berbasis akrual berpengaruh positif dan signifikan terhadap keterandalan pelaporan keuangan; (3) kualitas pelatihan berpengaruh positif dan signifikan terhadap keterandalan pelaporan keuangan.
\end{abstract}

\section{Pengutipan:}

Noviyanti, N.P., \& Devi, S. (2020). Pengaruh Pengawasan Keuangan, Penerapan Standar Akuntansi Pemerintah Berbasis Akrual, dan Kualitas Pelatihan Terhadap Keterandalan Pelaporan Keuangan. Jurnal IImiah Akuntansi dan Humanika, 10(2), 224-234

Keywords: financial control, implementation of accrual-based $S A P$, quality of training, reliability of financial reporting

\begin{abstract}
This research aims to understand the effect of financial control, the implementation of accrual-based government accounting standards, and the quality of training on the reliability of financial reporting. This type of research used is quantitative research. The population in this research is all employees of the financial sub division at 27 SKPD in Badung Regency. The sampling method used is purposive sampling. The number of samples in this research were 108 respondents. This research uses primary data obtained from distributing questionnaires directly to respondents. Data analysis techniques used include descriptive statistical tests, data quality tests, classic assumption tests, and hypothesis testing using multiple linear regression analysis using IBM SPSS Statistics 23. The research results prove that: (1) financial control has a positive and significant effect on reliability finance report; (2) the implementation of accrual-based government accounting standards has a positive and significant effect on the reliability of financial reporting; (3) the quality of training has a positive and significant effect on the reliability of financial reporting.
\end{abstract}

\section{Pendahuluan}

Laporan keuangan merupakan elemen yang esensial dalam terciptanya suatu akuntabilitas publik. Kini masyarakat menuntut agar penyelenggaraan pemerintah yang baik 
perlu untuk ditingkatkan, hal ini membuat pemerintah untuk terus berupaya dalam mengoptimalkan akuntabilitas publik. Laporan keuangan ini sebagai bukti pertanggungjawaban suatu kinerja entitas pada Lembaga pemerintahan yang diharapkan mampu menyajikan informasi secara jelas tentang kegiatan penilaian selama periode akuntansi (Ihsan, 2016). Informasi yang tersajikan dalam laporan keuangan tidak akan bermanfaat jika dalam penyampaian maupun penyajiannya tidak tepat waktu dan tidak dapat diandalkan (Larassati et al., 2017). Berdasarkan PP No. 71 Tahun 2010, laporan keuangan dikatakan andal ketika informasi yang tersajikan terbebas dari pemahaman yang mengelirukan pengguna, setiap fakta disajikan sesuai dengan keadaan sebenarnya, serta informasi dapat diuji kebenarannya (Peraturan BPK, 2010).

Namun faktanya BPK - RI masih menemukan adanya ketidaksesuaian data - data maupun permasalahan terkait pencatatan yang belum dilakukan secara akurat, terlambat menyampaikan laporan keuangan, serta proses penyusunan laporan keuangan yang belum sepenuhnya sesuai dengan SAP. Berdasarkan hasil penyelidikan BPK - RI dalam IHPS I Tahun 2019 terdapat 9.116 temuan yang memuat sebanyak 14.965 persoalan senilai $\mathrm{Rp}$ 10,35 triliun. Sebanyak 7.236 (48\%) meliputi permasalahan yang dikarenakan oleh lemahnya SPI. Sebanyak 7.636 (51\%) meliputi persoalan ketidaktaatan terhadap ketentuan yang berlaku. Ditemukan pula sebanyak $93(1 \%)$ permasalahan mengenai ketidakhematan, ketidakefisienan, dan ketidakefektifan sebesar Rp 676,81 miliar. Terdapat pula 2.798 (37\%) persoalan ketidaktaatan yang menimbulkan penyelewengan terhadap administrasi (Badan Pemeriksa Keuangan Republik Indonesia (BPK - RI ), 2019). Sehingga berdasarkan penyimpangan - penyimpangan yang ditemukan oleh BPK - RI tersebut menandakan bahwa kriteria andal dalam laporan keuangan belum sepenuhnya terpenuhi. Laporan keuangan bisa saja menyajikan informasi yang relevan, tetapi bila penyampaiannya tidak bisa diandalkan hal ini membuat pengguna tidak mempercayai informasi yang tersajikan dan secara potensial dapat menyesatkan dan merugikan penggunanya (Putra, 2017).

Pemerintah Kabupaten Badung berhasil memperoleh Opini Wajar Tanpa Pengecualian (WTP) selama lima kali beruntun mulai tahun 2014 sampai dengan tahun 2018 terkait pembuatan dan penyampaian Laporan Keuangan Pemerintah Daerah (LKPD) dengan perolehan standar tertinggi dalam Akuntansi dan Pelaporan Keuangan Pemerintah serta juga mendapatkan penghargaan dari Menteri Keuangan Republik Indonesia. Dijelaskan dengan pencapaian opini WTP, Pemerintah Kabupaten Badung membuktikan pengelolaan yang dilakukan sudah sangat baik serta akuntabilitasnya terjaga. Dikatakan juga bahwa dalam penyusunan dan penyajian LKPD, Pemerintah Kabupaten Badung tetap melaksanakan dan mengikuti regulasi yang ada (Radar Bali, 2019).

Bersumber pada hasil audit yang dilakukan oleh BPK - RI terkait pembuatan dan penyampaian Laporan Keuangan Pemerintah Daerah (LKPD), pada awalnya Pemkab Badung pernah meraih opini Wajar dengan Pengecualian (WDP) atas audit LKPD tahun anggaran 2010. Selanjutnya pada tahun 2011 dan 2012 Pemkab Badung berhasil meraih opini WTP. Namun pada tahun berikutnya justru meraih opini Tidak Wajar dari BPK atas audit LKPD 2013. Pemkab Badung mampu bangkit dan berhasil meraih kembali opini WTP atas audit LKPD tahun anggaran 2014 dan berlanjut selama lima kali berturut - turut sampai dengan tahun 2018. Namun berdasarkan Laporan Hasil Pengawasan (LHP) semester II tahun 2017 yang dilakukan oleh BPKP Provinsi Bali yang dilakukan pada Kabupaten Badung, Klungkung dan Buleleng masih ditemukan beberapa permasalahan terkait laporan keuangan seperti pengelola keuangan belum sepenuhnya paham mengenai mekanisme pencatatan keuangan, komponen laporan keuangan belum disusun secara lengkap, keterlambatan penyelesaian penyusunan LKPD, serta belum sepenuhnya memahami SAP. Selain temuan permasalahan dalam proses penyusunan Laporan Keuangan Pemerintah Daerah, BPKP Provinsi Bali juga melakukan Penghitungan Kerugian Keuangan Negara (PKKN) yang dilakukan atas permintaan dari Aparat Penegak Hukum (APH) dalam rangka membantu penyidikan. Berdasarkan Hasil Penghitungan Kerugian Keuangan Negara (PKKN) atas kasus dugaan Tindak Pidana Korupsi yang material di Kabupaten Badung adalah sebesar Rp 952.200.000,00. Kasus yang terjadi yaitu berupa pengambilalihan aset 
negara dengan pensertifikatan tanah, penyelewengan pengadaan barang dan jasa, penerimaan daerah yang tidak disetor, dan digunakan langsung untuk keperluan pribadi serta bantuan sosial dan hibah dari pemerintah (Badan Pengawasan Keuangan dan Pembangungan Provinsi Bali (BPKP), 2017).

Pengawasan keuangan merupakan salah satu faktor yang mempengaruhi keterandalan pelaporan keuangan. Agar menghasilkan informasi keuangan yang dapat diandalkan oleh pengguna, serta bersesuaian dengan konsep yang telah ditentukan pastinya dibutuhkan adanya pengawasan keuangan daerah. Untuk faktor selanjutnya adalah penerapan Standar Akuntansi Pemerintah (SAP) berbasis akrual. Standar Akuntansi Pemerintah (SAP) berbasis akrual menyajikan deskripsi yang lengkap mengenai kondisi keuangan pemerintah, mengungkapkan bagaimana pemerintah dapat memenuhi kebutuhan kasnya, bagaimana aktivitas pemerintah dibiayai, serta dapat meningkatkan daya pengelolaan anggaran, asset, dan kewajiban pemerintah (Sekretariat Daerah Kabupaten Badung, 2019). Kualitas pelatihan juga merupakan salah satu faktor yang mempunyai kontribusi dalam menghasilkan laporan keuangan yang andal. Sebuah keandalan laporan keuangan harus diperiksa dan dibuat oleh orang yang berkompeten agar bisa menyajikan sebuah laporan keuangan secara jujur dan wajar. Oleh karena itu sangat perlu diadakan suatu pelatihan keuangan yang memadai.

Penelitan ini berbeda dengan riset sebelumnya yang dilaksanakan oleh (Ihsan, 2016) dapat dilihat dari variabel yang digunakan serta lokasi penelitiannya. Pada riset sebelumnya hanya menggunakan satu variabel independen yakni efektivitas penerapan standar akuntansi pemerintahan serta lokasi penelitiannya yaitu pada Pemerintah Daerah Kabupaten Garut. Sedangkan pada riset ini menggunakan tiga variabel independen serta lokasi penelitiannya dilakukan pada SKPD Kabupaten Badung.

Berdasarkan uraian-uraian yang dikemukakan sebelumnya, rumusan masalah yang bisa dibahas dalam riset ini adalah(1) Apakah pengawasan keuangan berpengaruh terhadap keterandalan pelaporan keuangan; (2) Apakah penerapan Standar Akuntansi Pemerintah berbasis akrual berpengaruh terhadap keterandalan pelaporan keuangan; (3) Apakah kualitas pelatihan berpengaruh terhadap keterandalan pelaporan keuangan. Berdasarkan rumusan masalah diatas, adapun tujuan dari riset ini adalah untuk mengetahui pengaruh pengawasan keuangan, penerapan standar akuntansi pemerintah berbasis akrual, dan kualitas pelatihan secara parsial terhadap keterandalan pelaporan keuangan.

Pengawasan merupakan upaya sistematis dalam penetapan standar kinerja, untuk membandingkan standar kinerja yang sudah ditetapkan dengan kinerja sebenarnya, sebagai sarana untuk mendeteksi apakah terjadi suatu distorsi, dan ditujukan memastikan bahwa sumber daya pemerintahan telah dipergunakan secara efektif dan seefisien mungkin, sehingga target yang direncanakan dapat tercapai. Berdasarkan teori stewardship dimana pemerintah daerah (steward) berkewajibanuuntukmmemberikan pertanggungjawaban atas pengelolaan keuangan kepada masyarakat (principal) berupa laporan keuangan yang andal. Dalam usaha terwujudnya suatu laporan keuangan yang dapat diandalkan diperlukan adanya pengawasan keuangan yang memadai.

Penelitian mengenai pengawasan keuangan pernah dilakukan oleh (Anggaraeni, 2015), Megayanti (2015), (Larassati et al., 2017), (Putra, 2017) yang mengungkapkan bahwa pengawasan keuangan secara signifikan berpengaruh positif terhadap keterandalan pelaporan keuangan pemerintah daerah. Berlandaskan penjelasan di atas, maka hipotesis pertama yang diusulkan adalah:

\section{$\mathrm{H}_{1}$ : Pengawasan keuangan berpengaruh positif dan signifikan terhadap keterandalan pelaporan keuangan pemerintah daerah}

Akuntansi berbasis akrual yakni sebuah dasar akuntansi yang tidak memandang apakah kas atau setara kas telah dilunasi atau tidak, setiap terjadinya transaksi ekonomi proses pengakuan, pencatatan, dan penyajiannya dalam laporan keuangan dilakukan saat terjadinya transaksi tersebut. Berdasarkan teori stewardship pemerintah daerah (steward) 
dipandang mampu dalam membuat pertanggungjawaban berupa laporan keuangan yang dipercayakan kepadanya dengan melibatkan beberapa aturan yaitu berupa penerapan standar akuntansi pemerintah berbasis akrual. Adanya penggunaan standar akuntansi ini tentunya dapat meminimalisir dan mencegah terjadinya kekeliruan maupun kesalahan dalam proses pembuatan laporan keuangan.

Penelitian mengenai penerapan Standar Akuntansi Pemerintah (SAP) berbasis akrual pernah dilaksanakan oleh, (Asmarani, 2018), yang menunjukkan bahwa Standar Akuntansi Pemerintah (SAP) berbasis akrual berpengaruh positif dan signifikan terhadap keterandalan pelaporan keuangan daerah. Selain itu penelitian yang dilakukan (Prabawa, 2019) menunjukkan bahwa penerapan SAP berbasis akrual berpengaruh positif dan signifikan terhadap kualitas laporan keuangan. Berlandaskan penjelasan di atas, maka hipotesis kedua yang diusulkan adalah:

$\mathrm{H}_{2}$ : Penerapan Standar Akuntansi Pemerintah (SAP)
positif dan signifikan terhadap Akrual berpengaruh
keuangan pemerintah daerah.

Pelatihan merupakan metode pembelajaran dalam upaya mengoptimalkan keahlian Sumber Daya Manusia (SDM) dalam pelaksanaan tugasnya. Berdasarkan teori stewardship pemerintah daerah (steward) mempunyai kewajiban untuk membuat laporan pertanggungjawaban kepada masyarakat selaku principal atas pengelolaan keuangan yang telah dilakukan dalam bentuk laporan keuangan. Agar mampu terciptanya laporan keuangan yang andal tentunya dibutuhkan adanya suatu pelatihan kepada aparatur pemerintah. Penelitian mengenai pelatihan pernah dilakukan oleh (Laksmi, 2019), yang menerangkan bahwa pelatihan berpengaruh positif dan signifikan terhadap kualitas laporan keuangan. Selanjutnya riset yang dilaksanakan oleh (Dodopo et al., 2017) menunjukkan bahwa kualitas pelatihan memiliki pengaruh positif dan signifikan terhadap keterandalan laporan keuangan. Berlandaskan paparan di atas, maka hipotesis ketiga yang diusulkan yakni:

\section{$\mathrm{H}_{3}$ : Kualitas Pelatihan berpengaruh positif dan signifikan terhadap keterandalan pelaporan keuangan pemerintah daerah}

\section{Metode}

Tempat pelaksanaan penelitian ini adalah pada Satuan Kerja Perangkat Daerah (SKPD) Kabupaten Badung sejumlah 27 SKPD yang meliputi Dinas dan Badan. Rancangan penelitian yang dipergunakan adalah metode penelitian kuantitatif. Semua pegawai sub bagian keuangan pada 27 SKPD di Kabupaten Badung menjadi populasi dalam riset ini. Metode penentuan sampel yang dipergunakan yakni purposive sampling. Setiap SKPD diambil sejumlah 4 orang sebagai sampel. Sehingga sebanyak 108 orang menjadi responden pada riset ini. Data primer dipergunakan pada riset ini yang didapatkan dari pendistribusian angket secara langsung kepada responden dan skala likert 5 point menjadi alat ukurnya. Metode analisis data yang dipergunakan terdiri dari: uji statistik deskriptif, uji kualitas data yang meliputi uji validitas dan reliabilitas, uji asumsi klasik meliputi uji normalitas, uji multikolinieritas, dan uji heteroskedastisitas, serta pengujian hipotesis mempergunakan analisis regresi linear berganda, koefisien determinasi, uji parsial (uji t), dan uji f. Data yang dikumpulkan dalam penelitian ini diolah mempergunakan bantuan program IBM SPSS Statistics 23.

\section{Hasil dan Pembahasan}

Jumlah kuesioner yang didistribusikan setara dengan jumlah angket yang diterima kembali yaitu sejumlah 108 angket atau persentasenya 100\%. Dari jumlah tersebut tidak ada angket yang cacat, sehingga kuesioner yang bisa diolah dalam penelitian ini berjumlah 108 angket atau $100 \%$. Kuesioner yang didistribusikan terdiri dari 33 butir pernyataan yang meliputi 7 butir pernyataan untuk variabel Pengawasan Keuangan (X1), 9 item pernyataan untuk variabel Penerapan Standar Akuntansi Pemerintah Berbasis Akrual (X2), 9 butir 
pernyataan untuk variabel Kualitas Pelatihan (X3), dan 8 butir ppernyataan untuk variabel Keterandalan Pelaporan Keuangan (Y).

Bersumber dari hasil pengolahan data dari 108 kuesioner, dapat diketahui bahwa terdapat 42 responden laki-laki atau 38,9\%, sedangkan responden perempuan berjumlah 66 responden atau $61,1 \%$. Selanjutnya karakteristik responden berdasarkan usia diketahui bahwa dapat diketahui bahwa responden dengan usia 28-31 tahun sebanyak 2 responden atau sebesar 1,9\%, jumlah responden yang berusia $32-35$ sejumlah 4 responden atau sebesar 3,7\%, jumlah responden yang berusia 36-39 sebanyak 14 responden atau sebesar $13 \%$. Selanjutnya untuk responden yang berusia 40-44 sebanyak 26 responden atau sebesar 24,1\%, jumlah responden yang berusia $45-48$ sebanyak 16 responden atau sebesar 14,8\%, jumlah responden yang berusia 49-52 sebanyak 25 responden atau sebesar $23,1 \%$. Kemudian terdapat 16 responden atau sebesar 14,8\% berusia 53-56 tahun, dan sebanyak 5 responden atau sebesar 4,6\% berusia 57-60 tahun. Karakteristik responden berdasarkan pendidikan terakhir diketahui bahwa jumlah responden dengan pendidikan terakhir SMA adalah sejumlah 4 responden atau sebesar 3,7 $\%$. Kemudian jumlah responden dengan pendidikan terakhir $\mathrm{S} 1$ sejumlah 80 responden atau sebesar $74,1 \%$, serta terdapat 24 responden atau sebesar $22,2 \%$ responden dengan pendidikan terakhir S2. Serta penggolongan responden didasarkan pada masa kerja diketahui bahwa sejumlah 2 responden atau sebesar 1,9\% dengan masa kerja kurang dari 5 tahun, selanjutnya jumlah responden yang mempunyaimasa kerja diantara 5-10 tahun adalah sejumlah 20 responden atau sebesar 18,5\%, dan terdapat 86 responden atau sebesar 79,6\% mempunyai masa kerja lebih dari 10 tahun.

Berdasarkan hasil uji statistik deskriptif diketahui bahwa variabel pengawasan keuangan memiliki nilai minimum sebesar 27, nilai maksimum sebesar 35 , nilai mean sebesar 31,67 dan nilai standar deviasi sebesar 2,487. Variabel penerapan standar akuntansi pemerintah berbasis akrual memiliki nilai terendah sebesar 34, nilai tertinggi sebesar 45, nilai meansebesar 40,44 dan nilai standar deviasi adalah sebesar 3,259. Selanjutnya variabel kualitas pelatihan memiliki nilai minimum sebesar 30, nilai maksimum sebesar 45, nilai mean sebesar 38,81 dan nilai standar deviasi adalah sebesar 3,794. Serta variabel keterandalan pelaporan keuangan memiliki nilai terendah yakni 31 , nilai tertinggi yakni 45 , dengan nilai mean 36,21 dan nilai standar deviasi adalah sebesar 2,434. Hasil uji statistik deskriptif disajikan dalam tabel 1 . berikut.

Tabel 1. Hasil Uji Statistik Deskriptif

\begin{tabular}{lccccc}
\hline & N & Minimum & Maximum & Mean & Std. Deviation \\
\hline Pengawasan Keuangan (X1) & 108 & 27 & 35 & 31,67 & 2,487 \\
$\begin{array}{l}\text { Penerapan SAP Berbasis Akrual } \\
\text { (X2) }\end{array}$ & 108 & 34 & 45 & 40,44 & 3,259 \\
Kualitas Pelatihan (X3) & 108 & 30 & 45 & 38,81 & 3,794 \\
$\begin{array}{l}\text { Keterandalan Pelaporan } \\
\text { Keuangan (Y) }\end{array}$ & 108 & 31 & 40 & 36,21 & 2,434 \\
Valid N (listwise) & 108 & & & & \\
\hline
\end{tabular}

Sumber: data diolah, 2020

Tingkat kevalidan suatu angket dapat diukur dengan uji validitas, mempergunakan product momen Pearson correlation. Indikator maupun butir pernyataan dinyatakan valid bila $r_{\text {hitung }}>r_{\text {tabel }}$ atau nilai Sig. (2-tailed) $<0,05$. Jumlah sampel $(N)$ yang dipergunakan sejumlah 108 , sehingga $\mathrm{df}=\mathrm{N}-2=108-2=106$ dengan a 0,05. Maka diperoleh $r_{\text {tabel }}$ sebesar 0,1891 . Dari hasil pengujian validitas pada setiap variabel diperoleh rhitung $>r_{\text {tabel }} 0,1891$ serta nilai 
Sig. (2-tailed) $<0,05$, sehingga bisa ditarik kesimpulan bahwa seluruh butir pernyataan untuk setiap variabel adalah valid.

Uji reliability dipergunakan untuk menakar kestabilan setiap jawaban responden. Suatu angket dinyatakan reliabel apabila nilai Cronbach's Alpha > 0,70 (Ghozali, 2011). Berdasarkan hasil pengujian pada setiap variabel menunjukkan nilai Cronbach's Alpha seluruhnya di atas 0,70 sehingga dapat disimpulkan bahwa angket pengawasan keuangan, penerapan standar akuntansi pemerintah berbasis akrual, kualitas pelatihan, dan keterandalan pelaporan keuangan adalah reliabel.

Uji normalitas dilakukan untuk mengecek apakah pada model regresi suatu dependent variable dan independent variable terdistribusi secara normal atau tidak (Ghozali, 2011). Uji normalitas dijalankan dengan mempergunakan One Sample Kolmogorov-Smirnov Test. Bersumber dari tabel 2 menunjukkan bahwa nilai signifikansi (Asymp. Sig. (2-tailed) sebesar 0,200. Hal ini berarti nilai signifikansi (Asymp. Sig. (2-tailed) lebih besar dari 0,05 $(0,200>0,05)$. Sehingga kesimpulannya bahwa sebaran data dalam penelitian ini telah berdistribusi normal.

Tabel 2. Uji Normalitas

\begin{tabular}{llr}
\hline & One-Sample Kolgomorov-Smirnov Test & Unstandardized Residual \\
\hline $\mathrm{N}$ & & 108 \\
Normal Parameters & Mean & 0,0000000 \\
& Std. Deviation & 0,98680641 \\
Most Extreme Differences & Absolute & 0,056 \\
& Positive & 0,056 \\
& Negative & $-0,052$ \\
Test Statistic & & 0,056 \\
Asymp. Sig. (2-tailed) & & 0,200 \\
\hline
\end{tabular}

Uji multikolinieritas dimaksudkan untuk mengecek apakah ditemukan hubungan atau korelasi antara independent variable pada suatu model regresi (Ghozali, 2011). Bersumber dari tabel 3 dapat dilihat bahwa nilai tolerance pada setiap variabel bebas adalah lebih dari 0,10 . Demikian pula dengan nilai VIF pada setiap variabel bebas memiliki nilai kurang dari 10 . Sehingga disimpulkan bahwa tidak terjadi multikolinearitas pada model regresi.

Tabel. 3 Uji Multikolinieritas

\begin{tabular}{clcc}
\hline & \multicolumn{1}{c}{ Variabel } & \multicolumn{2}{c}{ Collinearity } \\
No. & & Statistics \\
\cline { 3 - 4 } & & 0,421 & Volerance \\
\hline 1. & Pengawasan Keuangan (X1) & 0,310 & 3,224 \\
2. & Penerapan SAP Berbasis Akrual (X2) & 0,422 & 2,369 \\
3. & Kualitas Pelatihan (X3) &
\end{tabular}

Sumber: data diolah, 2020

Uji heteroskedastisitas dimaksudkan untuk memahami apakah dalam model regresi terjadi perbedaan variansi dari residual pada satu pemantauan ke pemantauan lainnya (Ghozali, 2011). Pengujian yang dipergunakan untuk mengetahui terjadinya gejala heteroskedastisitas pada riset ini dilakukan dengan Uji Glejser. Berdasarkan tabel 4 dapat dilihat bahwa nilai signifikansi seluruh variabel mempunyai nilai lebih dari 0,05 . 
Sehingga bisa disimpulkan bahwa model regresiterlepas dari heteroskedatisitas atau tidak terjadi heteroskedatisitas.

Tabel.4 Uji Heteroskedastisitas

\begin{tabular}{|c|c|c|c|c|c|c|}
\hline \multirow{2}{*}{\multicolumn{2}{|c|}{ Model }} & \multicolumn{2}{|c|}{$\begin{array}{l}\text { Unstandardized } \\
\text { Coefficients }\end{array}$} & \multirow{2}{*}{$\begin{array}{c}\begin{array}{c}\text { Standardized } \\
\text { Coefficients }\end{array} \\
\text { Beta }\end{array}$} & \multirow[t]{2}{*}{$t$} & \multirow{2}{*}{ Sig. } \\
\hline & & $B$ & Std. Error & & & \\
\hline \multirow[t]{4}{*}{1} & (Constant) & 3,289 & 0,722 & & 4,555 & 0,000 \\
\hline & $X_{1}$ & $-0,035$ & 0,033 & $-0,150$ & $-1,052$ & 0,295 \\
\hline & $X_{2}$ & $-0,052$ & 0,030 & $-0,291$ & $-1,757$ & 0,082 \\
\hline & $X_{3}$ & 0,018 & 0,022 & 0,119 & 0,839 & 0,403 \\
\hline
\end{tabular}

a. Dependent Variable: Abs_RES

Sumber : data diolah, 2020

Analisis regresi linier berganda dimaksudkan untuk mengetahui hubungan diantara dua variabel bebas atau lebih terhadap suatu variabel terikat. Analisis regresi linier berganda dapat dilanjutkan karena seluruh uji asumsi klasik pada riset ini telah terpenuhi, yaitu sebaran data berdistribusi normal, antara variabel bebas tidak terjadi multikolinearitas, dan tidak terjadi heteroskedastisitas pada model regresi. Hasil uji regresi linear berganda dalam penelitian ini disajikan pada tabel 5. berikut ini.

Tabel 5. Hasil Uji Regresi Linear Berganda

\begin{tabular}{|c|c|c|c|c|c|c|}
\hline \multirow{2}{*}{\multicolumn{2}{|c|}{ Model }} & \multicolumn{2}{|c|}{$\begin{array}{c}\text { Unstandardized } \\
\text { Coefficients }\end{array}$} & \multirow{2}{*}{$\begin{array}{c}\text { Standardized } \\
\text { Coefficients } \\
\text { Beta }\end{array}$} & \multirow[t]{2}{*}{$t$} & \multirow[t]{2}{*}{ Sig. } \\
\hline & & $B$ & Std. Error & & & \\
\hline \multirow[t]{4}{*}{1} & (Constant) & 7,058 & 1,304 & & 5,411 & 0,000 \\
\hline & $\mathrm{X}_{1}$ & 0,239 & 0,060 & 0,244 & 3,985 & 0,000 \\
\hline & $X_{2}$ & 0,387 & 0,053 & 0,518 & 7,255 & 0,000 \\
\hline & $X_{3}$ & 0,153 & 0,039 & 0,239 & 3.905 & 0,000 \\
\hline
\end{tabular}

a. Dependent Variable: $\mathrm{Y}$

Sumber: data diolah, 2020

Keterangan: $X_{1}=$ Pengawasan Keuangan, $X_{2}=$ Penerapan SAP Berbasis Akrual, $X_{3}=$ Kualitas Pelatihan, dan $\mathrm{Y}=$ Keterandalan Pelaporan Keuangan

Bersumber pada tabel 5 didapatkan persamaan regresi sebagai berikut : $Y=7,058+$ $0,239 X_{1}+0,387 X_{2}+0,153 X_{3}+1,304 \ldots . .(1)$. Dari persamaan regresi tersebut dapat dijelaskan hasil sebagai berikut. Konstanta 7,058 menandakan jika variabel $X_{1}, X_{2}, X_{3}$ bernilai konstan, maka variabel $Y$ mempunyai nilai 7,058 satuan. $X_{1}$ memiliki koefisien regresi 0,239 . Nilai koefisien regresi yang positif menandakan bahwa $X_{1}$ berpengaruh positif terhadap $\mathrm{Y}$. Hal ini mencerminkan bahwa jika terjadi peningkatan pada $\mathrm{X}_{1}$ sebesar 1 satuan maka besarnya $Y$ juga akan meningkat sebesar 0,239 dengan anggapan variabel independen lainnya konstan. $X_{2}$ memiliki koefisien regresi 0,387. Nilai koefisien regresiyang positif mengindikasikan bahwa $X_{2}$ berpengaruh positif terhadap $Y$. Hal ini mencerminkan bahwa jika terjadi peningkatan pada $X_{2}$ sebesar 1 satuan maka besarnya $Y$ juga akan meningkat sebesar 0,387 dengan asumsi variabel independen lainnya konstan. $\mathrm{X}_{3}$ memiliki koefisienregresi 0,153 . Nilai koefisien regresi yang positif menunjukkan bahwa $X_{3}$ berpengaruh positif terhadap $Y$. Hal ini mencerminkan bahwa jika terjadi peningkatan pada $X_{3}$ sebesar 1 satuan maka besarnya $Y$ juga akan meningkat sebesar 0,153 dengan anggapan variabel independen lainnya konstan. 
Koefisien determinasi pada dasarnya dimaksudkan untuk menakar seberapa jauh kapabilitas dependent variable dapat dijelaskan oleh independent variable. Pada regresi linear berganda, untuk melihat seberapa baik kemampuan variabel dependen dijelaskan oleh variabel dependen dapat ditunjukkan dengan nilai Adjusted $\mathrm{R}$ Square. Capaian ujiikkoefisien determinasi dalam penelitian ini dapat dilihat pada tabel 6 . berikut.

Tabel 6. Hasil Uji Koefisien Determinasi

\begin{tabular}{ccccc}
\hline Model & $\mathbf{R}$ & R Square & Adjusted R Square & Std. Error of the Estimate \\
\hline 1 & 0,914 & 0,836 & 0,831 & 1,001
\end{tabular}

Sumber: data diolah, 2020

Berdasarkan tabel 6. dapat dilihat bahwa nilai Adjusted R Square sebesar 0,831. Hal ini menunjukkan bahwa $83,1 \%$ variabel keterandalan pelaporan keuangan dapat dijelaskan atau dipengaruhi oleh variabel pengawasan keuangan, penerapan standar akuntansi pemerintah berbasis akrual, dan kualitas pelatihan, sedangkan sisanya $16,9 \%$ dipengaruhi oleh faktor lain.

Uji parsial t dipergunakan untuk menguji besarnya korelasi suatu variabel independen secara individu dalam menginterpretasikan variasi variabel dependen. Jika nilai $t$ hitung $>t$ tabel maka variabel independen berpengaruh terhadap variabel dependen. Nilai $t$ tabel adalah sebesar 1,983. Selain itu dasar pengambilan keputusan dapat dilihat pula dengan nilai signifikansinya, jika nilai signifikansi $<0,05$ maka variabel independen berpengaruh signifikan terhadap variabel dependen.

Bersumber dari tabel 5. pada variable $X_{1}$ diperoleh bahwa $t_{\text {hitung }}$ sebesar $3,985>t_{\text {tabel }}$ 1,983 , dan nilai signifikansi $0,000<0,05$, selanjutnya pada variabel $\mathrm{X}_{2}$ diketahui bahwa thitung sebesar 7,255 $>t_{\text {tabel }} 1,983$, dan nilai signifikansi $0,000<0,05$, kemudian pada variable $\mathrm{X}_{3} \mathrm{t}_{\text {hitung }}$ sebesar 3,905 $>\mathrm{t}_{\text {tabel }} 1,983$, dan nilai signifikansi $0,000<0,05$. Nilai $\mathrm{t}$ positif memperlihatkan bahwa setiap variabel memiliki korelasi yang searah terhadap variabel $\mathrm{Y}$. Jadi dapat disimpulkan bahwa $\mathrm{H}_{1}$ diterima. Hal ini merefleksikan bahwa variabel pengawasan keuangan $\left(X_{1}\right)$, penerapan standar akuntansi pemerintah berbasis akrual $\left(X_{2}\right)$, dan kualitas pelatihan $\left(X_{3}\right)$ masing-masing berpengaruh positif dan signifikan terhadap keterandalan pelaporan keuangan.

Uji $f$ pada riset ini dimaksudkan untuk mengetahui kelayakan dari suatu model, apakah model dari analisis regresi berganda sudah fix atau belum. Apabila nilai sig yang diperoleh lebih kecil 0,05 atau $f$ hitung lebih dari $f_{\text {tabel }}$ maka model yang dipergunakan sudah fix atau model layak digunakan (Ghozali, 2011). Nilai $f$ tabel adalah sebesar 2,69. Bersumber dari hasil pengujian dapat diketahui bahwa nilai sig adalah sebesar 0,000 kurang dari 0,05 serta dapat diketahui bahwa nilai $f_{\text {hitung }}$ sebesar 176,305 lebih dari nilai $f_{\text {tabel }} 2,69$. Sehingga dapat disimpulkan bahwa model layak untuk dipergunakan.

\section{Pengaruh Pengawasan Keuangan Terhadap Keterandalan Pelaporan Keuangan}

Berdasarkan hasil pengujian hipotesis pertama pada uji statistik $t$, dapat disimpulkan bahwa $\mathbf{H}_{1}$ diterima sehingga pengawasan keuangan berpengaruh positif dan signifikan terhadap keterandalan pelaporan keuangan.

Hubungan antara pengawasan keuangan terhadap keterandalan pelaporan keuangan pada SKPD Kabupaten Badung adalah untuk dapat mewujudkan informasi keuangan yang semakin andal maka diperlukan adanya peningkatan pengawasan keuangan yang memadai terutama dalam proses pembuatan laporan. Hal ini sejalan dengan teori stewardship dimana pemerintah daerah (steward) berkewajiban untuk memberikan pertanggungjawaban atas pengelolaan keuangan kepada masyarakat (principal) berupa laporan keuangan yang andal.

Pemerintah Kabupaten Badung telah mewujudkan pengawasan yang efektif dan tepat sasaran terutama pada pembuatan laporan keuangan pemerintah. Pelaksanaan pengawasan keuangan mampu mendukung pemerintah dalam memantau setiap aktivitas 
yang dilaksanakan pada SKPD Kabupaten Badung dalam penggunaan anggaran maupun dalam hal penyusunan laporan keuangan. Pengawasan keuangan memiliki peranan yang sangat esensial terutama dalam cakupan organisasi pemerintah, hal ini bertujuan untuk menghindari terjadinya penyelewengan yang dilakukan oleh oknum tertentu sehingga dapat menimbulkan kerugian bagi pemerintah.

Hasil riset ini konsisten dengan penelitian yang dilaksanakan oleh (Anggaraeni, 2015), (Larassati et al., 2017), dan (Putra, 2017) yang mengungkapkan bahwa pengawasan keuangan berpengaruh positif dan signifikan terhadap keterandalan pelaporan keuangan.

\section{Pengaruh Penerapan Standar Akuntansi Pemerintah Berbasis Akrual Terhadap} Keterandalan Pelaporan Keuangan

Berdasarkan hasil pengujian hipotesis kedua pada uji statistik $t$, dapat disimpulkan bahwa $\mathbf{H}_{2}$ diterima sehingga penerapan standar akuntansi pemerintah berbasis akrual berpengaruh positif dan signifikan terhadap keterandalan pelaporan keuangan.

Hubungan antara penerapan standar akuntansi pemerintah berbasis akrual terhadap keterandalan pelaporan keuangan pada SKPD Kabupaten Badung adalah semakin optimal penerapan standar akuntansi pemerintah berbasis akrual yang dilakukan maka akan mampu memaksimalkan keterandalan pelaporan keuangan. Hal ini sesuai dengan teori stewardship dimana pemerintah daerah (steward) dipandang mampu dalam membuat pertanggungjawaban berupa laporan keuangan yang andal kepada publik selaku principal.

Dengan adanya penggunaan standar akuntansi pemerintah berbasis akrual pada SKPD Kabupaten Badung hal ini tentu akan memberikan manfaat bagi seluruh elemen yang memerlukan informasi karena accrual basis ini mampu memberikan deskripsi posisi keuangan pemerintah secara lengkap, sehingga nantinya informasi tersebut dapat dipergunakan sebagai pertimbangan dalam penentuan keputusan akan menjadi lebih efektif, akurat, serta dapat dipercaya oleh pengguna karena basis akrual telah menyajikan informasi yang lebih komprehensif.

Hasil riset ini konsisten dengan penelitian yang dilaksanakan oleh (Asmarani, 2018) yang mengungkapkan bahwa penerapan Standar Akuntansi Pemerintah (SAP) berpengaruh positif dan signifikan terhadap keterandalan pelaporan. Serta riset yang dilakukan oleh (Prabawa, 2019) yang menerangkan bahwa penerapan SAP berpengaruh positif dan signifikan terhadap kualitas laporan keuangan.

\section{Pengaruh Kualitas Pelatihan Terhadap Keterandalan Pelaporan Keuangan}

Berdasarkan hasil pengujian Ihipotesis ketiga pada uji statistik t, dapat disimpulkan bahwa $\mathbf{H}_{3}$ diterima sehingga kualitas pelatihan berpengaruh positif dan signifikan terhadap keterandalan pelaporan keuangan.

Hubungan antara kualitas pelatihan terhadap keterandalanpelaporan keuangan pada SKPD Kabupaten Badung yakni semakin berkualitas, kualitas pelatihan yang dilakukan maka akan bisa memaksimalkan serta meningkatkan keterandalan pelaporan keuangan. Hai ini sesuai dengan teori stewardship pemerintah daerah (steward) mempunyai kewajiban untuk membuat laporan pertanggungjawaban kepada masyarakat selaku principal atas pengelolaan keuangan yang telah dilakukan dalam bentuk laporan keuangan. Terwujudnya laporan keuangan yang andal tentunya dibutuhkan adanya suatu pelatihan kepada aparatur pemerintah.

Pemerintah Kabupaten Badung telah melaksanakan pelatihan pengelolaan keuangan daerah yang digunakan sebagai upaya peningkatan kompetensi aparatur, terutama bagi pengelola keuangan dilingkungan pemerintah Kabupaten Badung untuk selalu berusaha meningkatkan profesionalitasnya, sehingga dengan adanya kualitas pelatihan yang telah dilaksanakan dengan baik maka hal tersebut dapat meningkatan keterandalan pelaporan keuangan pada pemerintah kabupaten badung.

Hasil riset ini konsisten dengan penelitian yang dilaksanakan oleh (Dodopo et al., 2017) mengungkapkan bahwa variabel kualitas pelatihan berpengaruh positif dan 
signifikan terhadap keterandalan laporan keuangan. Selain itu penelitian yang dilaksanakan oleh Laksmi (2019) yang mengindikasikan bahwa kualitas pelatihan berpengaruh positif dan signifikan terhadap kualitas laporan keuangan.

\section{Simpulan dan Saran}

Bersumber pada hasil dan pembahasan di atas, maka dapat ditarik simpulan sebagai berikut :(1) Pengawasan keuangan berpengaruh positif dan signifikan terhadap keterandalan pelaporan keuangan; (2) Penerapan standar akuntansi pemerintah berbasis akrual berpengaruh positif dan signifikan terhadap keterandalan pelaporan keuangan: (3) Kualitas pelatihan berpengaruh positif dan signifikan terhadap keterandalan pelaporan keuangan.

Adapun saran dari riset ini yaitu bersumber pada hasil riset yang dicapai, adapun masukan yang diberikan yakni sebagai berikut: (1) Bagi Pemerintah Kabupaten Badung, agar lebih meningkatkan pengawasan keuangan terutama di dalam proses penyusunan LKPD. Selain itu penerapan standar akuntansi pemerintah berbasis akrual perlu diimbangi dengan pemahaman yang memadai dari aparatur, serta perlu diadakan suatu kegiatan sosialisasi secara berkala mengenai penerapan standar akuntansi pemerintah. Kedepannya perlu terus dilakukan upaya peningkatan kualitas pelatihan bagi aparatur pemerintah khususnya yang terlibat dalam proses penyusunan laporan keuangan; (2) Bagi penelitian selanjutnya disarankan untuk menambah jumlah sampel penelitian serta mengembangkan lagi penelitian seperti ini dengan menambahkan atau mengganti dengan faktor lain yang juga berdampak pada keterandalan pelaporan keuangan pemerintah daerah. Nilai adjusted $R$ Square sebesar 0,831 . Hal ini berarti bahwa $83,1 \%$ keterandalan pelaporan keuangan dipengaruhi oleh variabel pengawasan keuangan, penerapan standar akuntansi pemerintah berbasis akrual dan kualitas pelatihan sedangkan $16,9 \%$ dipengaruhi oleh faktor lain.

\section{Daftar Rujukan}

Anggaraeni, M. (2015). Pengaruh Pengawasan Keuangan, Penerapan Sistem Akuntansi Keuangan, dan Komitmen Manajemen Terhadap Keterandalan Pelaporan Keuangan Pemerintah Daerah (Studi Kasus Pada 15 Dinas SKPD Kabupaten Badung). Universitas Pendidikan Ganesha.

Asmarani, B. K. (2018). Pengaruh Pemanfaatan Teknologi Informasi, Pengendalian Intern Akuntansi dan Penerapan Standar Akuntansi Pemerintahan (Sap) Terhadap Keterandalan Pelaporan Keuangan Pemerintah Daerah Kabupaten Sragen. Program Studi Akuntansi, Fakultas Ekonomi dan Bisnis.

Badan Pemeriksa Keuangan Republik Indonesia (BPK - RI ). (2019). 2019. Ikhtisar Hasil Pemeriksaan Semester I Tahun 2019. http://www.bpk.go.id/.

Badan Pengawasan Keuangan dan Pembangungan Provinsi Bali (BPKP). (2017). Laporan Hasil Pengawasan Provinsi Bali 2017.

Dodopo, Y., Sondakh, J., \& Tinangon, J. (2017). PENGARUH KOMITMEN ORGANISASI, PENGENDALIAN INTERN AKUNTANSI, PERAN INTERNAL AUDIT, PENDIDIKAN, DAN KUALITAS PELATIHAN TERHADAP KETERANDALAN LAPORAN KEUANGAN PADA SKPD PEMERINTAH KABUPATEN HALMAHERA UTARA. JURNAL RISET AKUNTANSI DAN AUDITING “GOODWILL.” https://doi.org/10.35800/jjs.v8i1.15306

Ghozali. (2011). Aplikasi Analisis Multivariate dengan Program SPSS. Jurnal IImiah Universitas Pandanaran. https://doi.org/10.1177/107049659800700202 
Ihsan, A. M. (2016). Efektivitas Penerapan Standar Akuntansi Pemerintahan Terhadap Keterandalan Pelaporan Keuangan Pemerintah Daerah (Pada Pemerintahan Kabupaten Garut). Universitas Widyatama.

Laksmi, T. P. (2019). Pengaruh Sumber Daya Manusia, Kualitas Pelatihan, Pengalaman Kerja, dan Sistem Pengendalian Internal Terhadap Kualitas Laporan Keuangan (Studi Kasus pada Koperasi di Kabupaten Gianyar). Universitas Pendidikan Ganesha.

Larassati, P., Andreas, A., \& Supriono, S. (2017). PENGARUH PEMANFAATAN TEKNOLOGI INFORMASI PENGAWASAN KEUANGAN DAERAH SUMBER DAYA MANUSIA DAN PENGENDALIAN INTERN AKUNTANSI TERHADAP KETERANDALAN PELAPORAN KEUANGAN PEMERINTAH DAERAH (Studi Pada SKPD Kabupaten Indragiri Hulu). Jurnal Online Mahasiswa Fakultas Ekonomi Universitas Riau.

Peraturan BPK. (2010). Peraturan Pemerintah Nomor 71 Tahun 2010 Tentang Standar Akuntansi Pemerintah.

Prabawa, K. W. (2019). Pengaruh Penerapan Standar Akuntansi Pemerintah, Kualitas Sumber Daya Manusia, Sistem Pengendalian Internal, dan Komitmen Organisasi Terhadap Kualitas Laporan Keuangan (Studi Kasus pada SKPD Kabupaten Buleleng). Universitas Pendidikan Ganesha.

Putra, R. A. (2017). Pengaruh Kualitas Sumber Daya Manusia, Pemanfaatan Teknologi Informasi, Sistem Pengendalian Intern, Pengawasan Keuangan Daerah, dan Komitmen Manajemen Terhadap Keandalan Pelaporan Keuangan Pemerintah. JOM Fekon, Vol.4(No. 1).

Radar Bali. (2019). Raih Opini WTP 5 Kali Berturut-turut, Menkeu Apresiasi Pemerintah Kabupaten Badung. https://radarbali.jawapos.com/read/2019/10/29/163523/raih-opiniwtp-5-kali-berturut-turut-menkeu-apresiasi-pemkab-badung

Sekretariat Daerah Kabupaten Badung. (2019). Pelatihan Pengelolaan Keuangan Daerah di Lingkungan Pemerintah Kabupaten 2019. https://badungkab.go.id/instansi/setda/baca-berita/5070/Pelatihan-PengelolaanKeuangan-Daerah-di-Lingkungan-Pemerintah-Kabupaten-Badung-2019.html. 